\title{
Incidence of Mycoplasma Pneumoniae Infection in HIV Infected Patients With Underlying Upper and Lower Respiratory Complaints and Correlation With Various Immunological and Haematological Findings
}

\author{
EM Shankar*‡1, N Kumarasamy², P Balakrishnan², Suniti Solomon², \\ Bella Devaleenol ${ }^{2}$ and Usha Anand Rao ${ }^{1}$
}

\author{
Address: ${ }^{1}$ Mycoplasma Laboratory, Department of Microbiology, Dr. ALM PG Institute of Basic Medical Sciences, University of Madras, Taramani \\ Campus, Chennai, India and ${ }^{2}$ YRG Centre for AIDS Research \& Education, VHS, Taramani, Chennai, India \\ Email: EM Shankar* - nanjilemshankar@rediffmail.com \\ * Corresponding author $\ddagger$ Presenting author
}

from 2005 International Meeting of The Institute of Human Virology

Baltimore, USA, 29 August - 2 September 2005

Published: 8 December 2005

Retrovirology 2005, 2(Suppl I):S97 doi:10.1186/1742-4690-2-SI-S97

\section{Background and Objectives}

Mycoplasma pneumoniae has been implicated with community-acquired pneumonia and mild to severe respiratory infections in the normal population. The prevalence of this mollicute in HIV infected patients has never been reported from India. Mycoplasmas have also been reported to act as cofactors in AIDS progression.

\section{Aims and Objectives}

a) To divulge the incidence of Mycoplasma pneumoniae and other respiratory pathogens in the respiratory specimens of HIV infected patients.

b) To compare the sensitivities of induced sputum and throat swab specimens for detecting Mycoplasma pneumoniae.

c) To correlate the various haematological and immunological findings with infection due to $M$. pneumoniae in the HIV infected patients tested.

\section{Materials and methods}

The present study has been carried out on 60 HIV infected patients presenting with underlying pulmonary complaints and whose clinical presentation was consistent with disease caused by Mycoplasma pneumoniae, after obtaining informed consent subsequent to approval by the Institutional Review Board (IRB) on human ethics in Chennai where the recovery rates of Mycoplasma pneumo- niae from induced sputum and throat swab specimens of HIV infected patients were compared and the haematological and immunological findings were analysed. Patients screened were from the age groups ranging from 15 to 60 years, whose respiratory specimens were cultured on PPLO glucose agar and broth, the later with $1 \%$ methylene blue. Presumptive identification of Mycoplasma pneumoniae was carried out using guidelines proposed by the Subcommittee on the Taxonomy of Mollicutes, 1979. The respiratory specimens from the HIV-infected subjects were later analysed for their recovery rates, incidence of other bacterial, fungal pathogens, AFB, Pneumocystis carinii and their correlation features with $\mathrm{CD} 4+$ and CD8+ lymphocytes were also analysed and compared.

\section{Results and Conclusion}

The male to female ratio of the study population was 51:09. The mean age of the patients was 39 years. M. pneumoniae was presumptively detected from 23 (38.3\%) of the HIV infected patients. Induced sputum and throat swabs yielded $82.6 \%$ and $55 \%$ of the mycoplasma isolates respectively, which suggests that induced sputum can be the better specimen compared to throat swabs. Simultaneous positivity of both specimens was detected in 13 (56.5\%) cases. Besides Candida spp (80\%), Staphylococcus aureus $(26.6 \%)$, Streptococcus pneumoniae (21.6\%), Pseudomonas aeruginosa $(18.3 \%)$, AFB (16.6\%), Klebsiella pneumoniae (15\%), Moraxella catarrhalis $(8.3 \%)$, b-hemolytic streptococci, P. carinii, M. fermentans (6.6\%), diphtheroids 
(5\%), A. fumigatus and E. coli (1.6\%) were the predominant isolates. The detection rate of $M$. pneumoniae was found to be high in patients with depleted CD4 levels. The mean CD 4 count of the study cases was 106 cells/ $\mu \mathrm{l}$, whereas the value was only 78 cells/ $\mu$ lamong those positive for Mycoplasma pneumoniae. The study shows that CD4 depletion may enhance mycoplasma infection in the respiratory tracts of HIV infected patients.

Publish with Bio Med Central and every scientist can read your work free of charge

"BioMed Central will be the most significant development for disseminating the results of biomedical research in our lifetime. " Sir Paul Nurse, Cancer Research UK

Your research papers will be:

- available free of charge to the entire biomedical community

- peer reviewed and published immediately upon acceptance

- cited in PubMed and archived on PubMed Central

- yours - you keep the copyright

Submit your manuscript here:

http://www.biomedcentral.com/info/publishing_adv.asp 